\title{
James Baker's brave new world
}

The US Secretary of State is rightly cock-a-hoop about the prospects for arms control in the near future, but his vision of what follows is incomplete. But it is not too soon to be planning for the post-strategic world.

THE US Secretary of State, Mr James Baker, broke new ground on arms control in his speech in San Francisco last week. Telling how the prospects for far-reaching arms control agreements have been brightened in the past few years, he argued for paying attention now to the arrangements that will be necessary when the agreements now being negotiated have been signed and ratified. At this stage, Baker is doing little more than to think aloud, but it is radical thinking. Can he carry the rest of the US administration with him?

The list of agreements to which lawyers are putting the finishing touches is impressive. That on strategic arms has been made possible by the Soviet government's willingness to decouple the prospective agreement on strategic weapons from the Strategic Defense Initiative (SDI). That, Baker says, will be pursued within the confines of the Anti-Ballistic Missile Treaty. The objective, now, is to eliminate first-strike weapons. On conventional weapons, the superpowers seem to be moving towards an agreement based on the limitation of offensive weapons. A chemical weapons agreement is also almost within sight - the United States will destroy 80 per cent of its stocks on signature, and the Soviet Union will reduce its stocks to the same level, stocks will be reduced by a further factor of ten within eight years of a multilateral treaty and all chemical weapons will be destroyed when all states capable of making them have joined the treaty. It is a breathtaking prospect.

Is it likely to become a reality? Baker's new thinking, as perestroika would have it, takes the form of an open calculation of the chances. "We want perestroika to succeed", he says; "it would be folly indeed to miss this opportunity." But what if perestroika fails, and if the warp of history is rolled back? Then there will be arms control agreements in place, which the Soviet Union will be able to disown only with great difficulty, even risk. And, by implication, arms control agreements may even help perestroika. So far, so good.

What follows? One ingredient of the regime to come, in Baker's view, is the strategic glasnost provided by the arrangements for verification being written into the arms control treaties. Then, he says, there will be an opportunity also to deal with issues such as the proliferation of missile-making capacity, when the United States and the Soviet Union will be able to make common cause (as, fair play, they have done from the start on nuclear weapons).
That, he says, will also be the time to embark on the "institutionalization of a safer world".

But need it wait that long? If perestroika has brightened the outlook, it has also deepened some uncertainties, not only in Central Europe, but in the Middle East, the Far East and in South-East Asia. What will happen if Hungary applies to join the European Communities, or seeks to renew its old alliance with Austria? Will the problems of the Middle East spill northwards, through Iran? How will withdrawn-again China react? Where does Japan stand in this changing world? The simple answer is that nobody can tell, which is one of the reasons why present circumstances are cheerful. But that is also a good reason why the "institutionalization" of the safer world cannot be left to the United States and the Soviet Union alone. What Baker needs now, is a political agreement with Western Europe, Japan and the Soviet Union on the future exercise of their political and economic influence. Horse-trading on technology transfer is bound to be an important ingredient, mere money another.

\section{Diplomacy please}

The US human genome project must be mounted internationally, and others must help pay for it.

THE project to sequence the human genome is running into avoidable heavy weather. That is one conclusion drawn from reports last week of the meeting between $\mathrm{Dr}$ James Watson, the director of the project for the National Institutes of Health (NIH), and the House of Representatives subcommittee (see Nature 341, 679; 26 October 1989). One teasing issue is that of proprietary rights to whatever sequence emerges. Watson seems not greatly to have exerted himself in disabusing congressmen of the fear that spending $\$ 3,000$ million of US taxpayers' money would be a gift to the world's biotechnology industry.

In principle, this is a serious issue. Given a complete map of the human genome, commercial companies could scan it for interesting genes or arrangements of genes. Given the possibility that, 15 years from now, much more will be known of how the products of one gene regulate another, a complete sequence may yield even more subtle information about human pathology, and about the usefulness of drugs, synthetic or otherwise. But that is not 